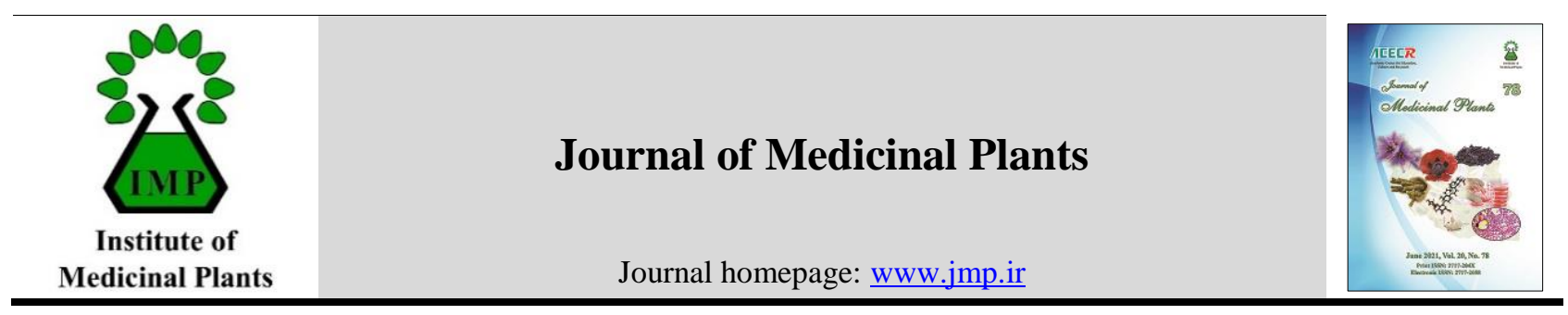

Research Article

\title{
Formulation and quality evaluation of Coriander Triphala tablet
}

\author{
Rasool Choopani ${ }^{1}$, Homa Hajimehdipoor ${ }^{2, *}$, Karam Molaei ${ }^{3}$, Haniye Kashafroodi ${ }^{3}$, Fatemeh \\ Tavakolifar ${ }^{3}$, Leila $\mathrm{Ara}^{3}$
}

${ }^{1}$ Traditional Medicine and Materia Medica Research Center and Department of Traditional Medicine, School of Traditional Medicine, Shahid Beheshti University of Medical Sciences, Tehran, Iran

${ }^{2}$ Traditional Medicine and Materia Medica Research Center and Department of Traditional Pharmacy, School of Traditional Medicine, Shahid Beheshti University of Medical Sciences, Tehran, Iran

${ }^{3}$ Traditional Medicine and Materia Medica Research Center, Shahid Beheshti University of Medical Sciences, Tehran, Iran

\begin{tabular}{|c|c|}
\hline ARTICLE INFO & ABSTRACT \\
\hline $\begin{array}{l}\text { Keywords: } \\
\text { Coriander Triphala } \\
\text { Tablet } \\
\text { Formulation } \\
\text { Iranian traditional } \\
\text { medicine } \\
\text { Quality control }\end{array}$ & $\begin{array}{l}\text { Background: Coriander Triphala is one of the famous drugs in traditional medicine which } \\
\text { is consisted of Terminalia chebula, T. bellirica, Phyllanthus emblica, Coriandrum sativum, } \\
\text { almond oil and honey. Traditional dosage forms should be converted to modern forms for } \\
\text { better acceptance and suitable characteristics and stability. Objective: In the present } \\
\text { investigation, the traditional form of Coriander Triphala was converted to film coated tablet } \\
\text { and quality control of the tablet was performed. Methods: The fruits of } \\
\text { T. chebula, T. bellirica, Ph. emblica, C. sativum in equal proportions along with almond oil } \\
\text { and honey in different proportions were used for tablet formulation with other excipients. } \\
\text { Sixteen formulations were made and after pre-formulation studies, twelve of them were } \\
\text { selected for making tablet. Prepared tablets went through primary quality control tests such } \\
\text { as weight variation, friability, hardness and disintegration time. Finally, the best formulation } \\
\text { was coated by green colored water soluble material and its physicochemical characteristics } \\
\text { were determined. Results: Among different formulations, the tablet consisted of } 98 \mathrm{mg} \text { of } \\
\text { each species, } 14 \mathrm{mg} \text { almond oil, } 148 \mathrm{mg} \text { honey along with lactose, Avicel PH-102, } \\
\text { croscarmellose sodium, PVP K30, magnesium stearate and silicone dioxide was the best } \\
\text { one. Weight variation, hardness, disintegration time, total tannins content as pyrogallol were } \\
\text { found } 1225 \mathrm{mg} \pm 5 \%, 20 \mathrm{kp}, 25 \mathrm{~min} \text { and } 64.19 \mathrm{mg} / \text { tablet, respectively. Over } 90 \% \text { of tannins } \\
\text { were released after } 60 \text { min during dissolution test. Conclusion: The formulated tablet with } \\
\text { suitable characteristics is a good substitution for traditional form and could be produced in } \\
\text { industrial scale after complementary clinical trial studies. }\end{array}$ \\
\hline
\end{tabular}

Abbreviations: T. chebula, Terminalia chebula; T. bellirica, Terminalia bellirica; Ph. emblica, Phyllanthus emblica; PVP K30, Polyvinylpyrrolidone K30; CCS, Croscarmellose Sodium; $\mathrm{SiO}_{2}$, Colloidal Silicon Dioxide; MgSt, Magnesium Stearate

* Corresponding author: hajimehd@sbmu.ac.ir

doi: $10.52547 /$ jmp. 20.78 .68

Received 30 January 2021; Received in revised form 17 May 2021; Accepted 18 May 2021

(C) 2020. Open access. This article is distributed under the terms of the Creative Commons Attribution-NonCommercial 4.0 International License (https://creativecommons.org/licenses/by-nc/4.0/) 


\section{Introduction}

Plants have been widely used as medicine to treat diseases in the traditional systems from the ancient times throughout the world [1]. Therapeutic effects of many of medicinal plants have been documented so far. However, consumption of traditional formulations is inconvenient to the patients especially due to inappropriate taste and appearance [2]. Hence, many attempts have been performed to prepare new formulations in order to improve patient compliance and acceptability. During last decades, awareness of herbal formulations has been increased, but information about quality control parameters which are available for allopathic formulations is not available for majority of herbal products; therefore, it is necessary to develop different herbal formulations and their evaluations [3]. In Iranian traditional medicine, many natural prescriptions are used for treatment of various diseases. Coriander Triphala is an Iranian traditional formulation (semi-solid form) consisting of fruits of Terminalia chebula (three kinds of fruits: unripe, adult and fully matured fruits), T. bellirica, Phyllanthus emblica and Coriandrum sativum along with almond oil and honey. It is widely prescribed as a purgative, gastrointestinal and mental tonic [4-6].

Terminalia chebula Retz. is a plant species belonging to Combretaceae family. Three types of $T$. chebula fruits exist with different stages of maturity: small myrobalan: the unripe fruit, yellow myrobalan: the adult stage of the fruit after the development of seed, and large myrobalan: the fully matured fruit [7, 8]. All of these fruits are used in traditional medicine for different purposes. The fruits are rich in tannins which are pyrogallol type such as chebulic acid, chebulagic acid, corilagin and gallic acid [9]. This plant has been extensively used in traditional medicine systems especially in Iranian traditional medicine, Ayurveda, Unani and Homoeopathic medicine and has become a cynosure of modern medicine. It is mainly used in treatment of constipation, diarrhea, ulcers, gastroenteritis, asthma, cough, dyspnea, dyspepsia, hemorrhoids, skin diseases, memory loss and depression [10].

Terminalia bellirica (Gaertn.) Roxb. is another constituent of Coriander Triphala which mainly consists of tannins components such as gallic acid, ellagic acid, methyl gallate, ethyl gallate, chebulagic acid and hexahydroxydiphenic acid ester. Plant fruits are laxative, astringent, anthelmintic, antipyretic and are useful in hepatitis, bronchitis, asthma, dyspepsia, diarrhea and cough and also are used as hair tonic $[11,12]$.

Phyllanthus emblica L. (Phyllanthaceae) is one of the most common medicinal herb used in traditional medicine. It has been used as medicine and nutritious tonic, containing tannins, vital amino acids and vitamins. It is considered as a source of vitamin $\mathrm{C}$ and minerals. The fruits have been utilized for management of various diseases such as diabetes, hyperlipidemia, CNS disorders and ophthalmic diseases from the ancient time [13].

Coriandrum sativum L. (Apiaceae) is one of the oldest spices in the world. The use of this plant dated back to around $1550 \mathrm{BC}$. The seeds were used in many prescriptions as carminative agent and for the treatment of fever, diarrhea, vomiting, indigestion, memory loss and also as a tonic. The most important constituents of the fruits are the essential and fatty oils [14].

According to Iranian traditional medicine prescriptions, herbal powder of Coriander Triphala (equal proportion of each six plants) is mixed with almond oil and then, honey is added to the mixture. The last product is a semi solid 
dosage form with astringent and bitter taste which has low acceptability by the patients; therefore, transforming the traditional form to a modern dosage form is necessary. Tablet is one of the most acceptable dosage form among patients. Moreover, tablet is the most favorite dosage forms among manufacturers due to high stability, easier transportation and storage [15, 16]. Manufacturing of tablets should be followed by quality control tests to ensure consistent efficacy and safety as well. In the present investigation, Coriander Triphala semi solid traditional form was formulated as a film coated tablet and its characteristics were evaluated.

\section{Methods}

\subsection{Plant materials}

All required herbs were purchased from local markets in Tehran, Iran. They were identified in Traditional Medicine and Materia Medica Research Center (TMRC), Shahid Beheshti University of Medical Sciences, Tehran, Iran and their specimens were deposited at TMRC Herbarium for further reference (No. HMS 537HMS 542, for $T$. bellirica, Ph. Emblica, T. chebula (small myrobalan), T. chebula (yellow myrobalan), C. sativum and T. chebula (large myrobalan), respectively). Honey and almond oil were prepared from Honey Taj and Tuba companies, Iran, respectively.

\subsection{Chemicals}

Lactose was purchased from Armor Co. (France). Avicel PH-101 and -102 were prepared from FM (Ireland). Croscarmellose sodium was from Hiranya cellulose product Co. (India). Magnesium stearate was from Sun Here Co. (China) and colloidal silicon dioxide was prepared from Evonik (Germany). FolinCiocalteu and hide powder were from Merck (Germany) and Sigma (USA), respectively.
Other chemicals and solvents were provided from Merck (Germany).

\subsection{Instrumentation}

The hardness of the tablets was determined using a hardness tester (Model TB H28, Erweka, Germany). Friability tester, disintegrator and dissolution tester were from Noavaran Co., Iran. The tablets were pressed with single-punch tablet machine (Noavaran Co., Iran).

\subsection{Physicochemical analysis of crude herbs}

Quality control assessments were performed for each herbal sample. Total ash, loss on drying, alcohol and water soluble extractives were determined and evaluated according to pharmacopeia [17]. Total tannins content for Triphala plants and essential oil content for C. sativum were measured $[17,18]$.

\subsection{Pre-formulation studies}

According to traditional prescriptions, equal proportions of each the six plants should be powdered. Almond oil is added to T. chebula, T. bellerica and Ph. emblica powders (Triphala powder). Then the powder is mixed with coriander and honey, respectively. The usual dosage of this formulation in Iranian traditional clinics is $1.5-2 \mathrm{~g} / \mathrm{day}$.

In this experiment, the equal proportion of herbal materials along with different amounts of almond oil, honey and different excipients were used to prepare sixteen formulations. The amount of active constituents in each tablet was considered $750 \mathrm{mg}$. All species in equal portion were powdered. Triphala powders were mixed and almond oil was added to the mixture. Then C. sativum powder was added. Honey and PVP K30 were used in different portions to make granules. The granules were dried and passed via sieve 14. Lactose, Avicel PH-101 and -102, 
colloidal silicone dioxide, croscarmellose sodium and magnesium stearate were added to granules (Table 1). Then, the flowability of formulations was determined on the basis of
Carr's index, Hausner ratio and angle of repose and those formulations with good flowability characteristics were selected for making tablet $[19,20]$.

Table 1. Different formulations of Coriander Triphala tablet

\begin{tabular}{|c|c|c|c|c|c|c|c|c|c|c|c|}
\hline \multirow[b]{2}{*}{ No. } & \multicolumn{10}{|c|}{ Ingredient (mg) } & \multirow[b]{2}{*}{$\begin{array}{c}\text { Weight } \\
\text { (mg) }\end{array}$} \\
\hline & 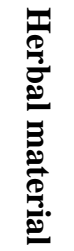 & 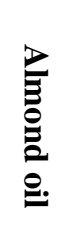 & 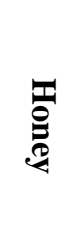 & 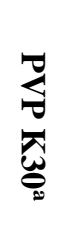 & 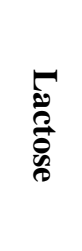 & 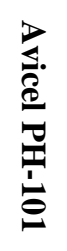 & 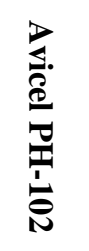 & $\mathscr{D}_{0}^{\infty}$ & 2ิ & 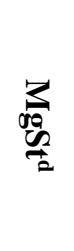 & \\
\hline F1 & 630 & 20 & 100 & 80 & 350 & - & - & 10 & - & 10 & 1200 \\
\hline F2 & 696 & 14 & 40 & 80 & 350 & - & - & 10 & - & 10 & 1200 \\
\hline F3 & 546 & 13 & 191 & 80 & 350 & - & - & 10 & - & 10 & 1200 \\
\hline $\mathrm{F} 4$ & 546 & 13 & 191 & 80 & 350 & - & - & 10 & 30 & 10 & 1230 \\
\hline F5 & 546 & 13 & 191 & 80 & 350 & - & - & 10 & $50^{\mathrm{e}}$ & 10 & 1250 \\
\hline F6 & 546 & 13 & 191 & 80 & 350 & - & - & 10 & $50^{\mathrm{f}}$ & 10 & 1250 \\
\hline F7 & 546 & 13 & 191 & 80 & - & - & 310 & 10 & 40 & 10 & 1200 \\
\hline F8 & 630 & 20 & 100 & 80 & 280 & - & - & - & 70 & 10 & 1200 \\
\hline F9 & 630 & 20 & 100 & 45 & 315 & - & - & 10 & 70 & $` 10$ & 1200 \\
\hline F10 & 630 & 20 & 100 & - & 315 & - & - & 10 & 70 & 10 & 1155 \\
\hline F11 & 588 & 14 & 148 & 47 & - & - & 370 & 20 & 58 & 5 & 1250 \\
\hline F12 & 588 & 14 & 148 & 47 & - & 74 & 296 & 10 & - & 5 & 1182 \\
\hline F13 & 588 & 14 & 148 & 47 & - & 74 & 298 & 10 & 48 & 5 & 1232 \\
\hline F14 & 588 & 14 & 148 & 42 & - & 74 & 296 & 10 & 25 & 5 & 1202 \\
\hline F15 & 588 & 14 & 148 & 48 & - & 36 & 324 & 10 & 19 & 5 & 1192 \\
\hline F16 & 588 & 14 & 148 & 42 & 60 & - & 300 & 10 & 25 & 5 & 1192 \\
\hline
\end{tabular}

a: PVP K30: Polyvinylpyrrolidone $\mathrm{K}_{30}{ }^{\mathrm{b}}{ }^{\text {: }} \mathrm{SiO}_{2}$ : colloidal silicon dioxide; ${ }^{\mathrm{c}}$ : $\mathrm{CCS}$ : Croscarmellose sodium; ${ }^{\mathrm{d}}:$ Magnesium stearate; ${ }^{\mathrm{e}}: 30 \mathrm{mg}$ intragranular and $20 \mathrm{mg}$ extragranular; ${ }^{\mathrm{f}}: 20 \mathrm{mg}$ intragranular and $30 \mathrm{mg}$ extragranular

\subsection{Preparation of Coriander Triphala tablets}

Regarding the pre-formulation studies, best formulations (F1-6, F11-16) were pressed by concave, oval, single-punch tablet machine. Then physical properties of tablets were evaluated. Considering the results, the more suitable formulation (16) was selected. To improve the appearance of the tablet, protect the components, especially essential oil of C. sativum from degradation and evaporation during storage and to cover the unpleasant taste, smell and color, the tablets were coated using a ready-to-use water soluble film coating powder with green color (concentration $20 \%$ in water). Film coating process was performed by using coating machine.

\subsection{Quality control of Coriander Triphala tablets}

The prepared tablets (core and coated tablets) underwent various physiochemical tests and pharmaceutical parameters, including 
appearance, diameter, thickness, weight variation, friability, disintegration time, hardness, assay of total tannins and dissolution behavior according to USP [21].

\subsection{Assay of total tannins as pyrogallol in tablets}

Since tannins are the main constituent in tablet ingredients, the content of total tannins as pyrogallol was assessed in tablets according to BP [17]. Briefly, ten tablets were powdered. To $100 \mathrm{mg}$ of the drug powder in a $100 \mathrm{~mL}$ volumetric flask, $80 \mathrm{~mL}$ of water was added and heated for $30 \mathrm{~min}$. Then the mixture was diluted to $100 \mathrm{~mL}$ with water. Two $\mathrm{mL}$ of this solution was mixed with $1 \mathrm{~mL}$ of Folin-Ciocalteu reagent and $10 \mathrm{~mL}$ of water and diluted to $25 \mathrm{~mL}$ with 29 $\%$ solution of sodium carbonate. After $30 \mathrm{~min}$ in dark place, the absorbance was measured at 760 $\mathrm{nm}$ using water as the compensation liquid. This absorption is related to total phenols. For quantitation of tannins, the content of polyphenols not adsorbed by hide powder were determined as following: to $10 \mathrm{~mL}$ of the extract, $100 \mathrm{mg}$ of hide powder was added and shaken vigorously for $60 \mathrm{~min}$. The mixture was filtered and the above-mentioned process was performed on the mixture. The difference between two measured absorbance is related to the tannins. Total tannins content of Coriander Triphala tablet was determined by using calibration curve of pyrogallol as standard material.

\subsection{Dissolution test of Coriander Triphala tablet}

Dissolution test was performed on six tablets. The USP apparatus 2 (paddle) at a speed of 100 $\mathrm{rpm}$, with $900 \mathrm{ml}$ distilled water as the dissolution medium at $37{ }^{\circ} \mathrm{C}$ was used and the samples were analyzed after 30, 45 and $60 \mathrm{~min}$. The percentage of released total tannins was determined using $5 \mathrm{ml}$ filtered portions of the samples.

\subsection{Stability assessment of Coriander Triphala tablets}

Laboratory accelerated stability test was performed on Coriander Triphala film coated tablets. Fifty tablets were packed in a polyethylene container and kept at $40{ }^{\circ} \mathrm{C} \pm 2$ temperature and $75 \% \pm 5$ humidity for 6 months. Then the tablets characteristics were determined [22].

Table 2. Results of quality control tests of Coriander Triphala tablet constituents

\begin{tabular}{|c|c|c|c|c|c|c|}
\hline $\begin{array}{l}\text { Name } \\
\text { Test }\end{array}$ & $\underset{\%}{\text { Total Ash }}$ & $\begin{array}{l}\text { Loss on } \\
\text { Drying \% }\end{array}$ & $\begin{array}{c}\text { Alcohol } \\
\text { soluble } \\
\text { extractive \% }\end{array}$ & $\begin{array}{c}\text { Water } \\
\text { soluble } \\
\text { extractive \% }\end{array}$ & $\begin{array}{c}\text { Total tannins } \\
\text { as pyrogallol } \\
\%\end{array}$ & $\begin{array}{c}\text { Essential oil } \\
\%\end{array}$ \\
\hline $\begin{array}{l}\text { Terminalia chebula } \\
\text { (Small myrobalan) }\end{array}$ & 2.54 & 3.49 & - & 44.01 & 26.72 & - \\
\hline $\begin{array}{l}\text { Terminalia chebula } \\
\text { (Yellow myrobalan) }\end{array}$ & $\begin{array}{c}2.68 \\
\text { (NMT 5)* }\end{array}$ & $\begin{array}{c}2.66 \\
(\mathrm{NMT} 10)\end{array}$ & - & $\begin{array}{c}50.97 \\
\text { (NLT 50) }\end{array}$ & $\begin{array}{c}26.14 \\
\text { (NLT 20) }\end{array}$ & - \\
\hline $\begin{array}{l}\text { Terminalia chebula } \\
\text { (Large myrobalan) }\end{array}$ & $\begin{array}{c}2.75 \\
\text { (NMT 5) }\end{array}$ & $\begin{array}{c}3.02 \\
(\mathrm{NMT} 10)\end{array}$ & - & $\begin{array}{c}61.07 \\
\text { (NLT 50) }\end{array}$ & $\begin{array}{c}24.00 \\
(\mathrm{NLT} 20)\end{array}$ & - \\
\hline Terminalia bellirica & $\begin{array}{c}2.85 \\
\text { (NMT 7) }\end{array}$ & $\begin{array}{c}2.47 \\
\text { (NMT 5) }\end{array}$ & - & $\begin{array}{c}51.99 \\
\text { (NLT 45) }\end{array}$ & $\begin{array}{c}11.02 \\
\text { (NLT 10) }\end{array}$ & - \\
\hline Phyllanthus emblica & $\begin{array}{c}3.62 \\
\text { (NMT 7) }\end{array}$ & $\begin{array}{c}2.81 \\
\text { (NMT 10) }\end{array}$ & $\begin{array}{c}22.64 \\
(\mathrm{NLT} 15)\end{array}$ & $\begin{array}{c}53.39 \\
(\text { NLT 50) }\end{array}$ & $\begin{array}{c}7.00 \\
(\mathrm{NLT} 6)\end{array}$ & - \\
\hline Coriandrum sativum & $\begin{array}{c}6.16 \\
\text { (NMT 8) }\end{array}$ & $\begin{array}{c}2.62 \\
(\mathrm{NMT} 10)\end{array}$ & - & - & - & $\begin{array}{c}0.4 \% \\
(\text { NLT } 0.3 \%)\end{array}$ \\
\hline
\end{tabular}

*Acceptable range according to British Pharmacopoeia; There is no monograph for small myrobalan in Pharmacopoeias. 


\section{Results}

The results of physicochemical analysis of crude herbs have been reported in Table 2. All plants showed acceptable physicochemical characteristics according to British Pharmacopoeia [17].

In Iranian traditional texts, the percentage of almond oil and honey has not been determined. Almond oil should be added to Triphala powders in minimum concentration just in amount to change the powder color. The amount of honey is different in prescriptions and its exact percentage is also unclear; therefore, during recent study, in all formulations, proportion of six herbals was considered equal and the concentrations of almond oil and honey have been changed to obtain $750 \mathrm{mg}$ of natural ingredients. In the first formulation, due to high amount of almond oil, the finished product was oily. Moreover, disintegration time was found over $60 \mathrm{~min}$. In order to overcome these problems, oil and honey concentrations were reduced but honey reduction, resulted low hardness and compressibility which cause some problems during coating. In the next process, oil reduction and honey addition were applied but due to honey rising, disintegration time was increased. So, the usage of a disintegrant such as croscarmellose sodium was necessary [23]. It was added to the formulations in different quantities as intra- and extragranular excipient $(F 4,5,6)$, but no reasonable disintegration time obtained. Accordingly, it was decided to change lactose with Avicel which had not only binder, diluent and lubricant effects but also had disintegrant property. However granule formation was not reasonable along with weak flowability characteristic (F7). Thus, Avicel was replaced by lactose, $\mathrm{SiO}_{2}$ omitted and croscarmellose sodium percentage was increased which resulted low flowability (F8). In the next step, it was decided to decrease PVP K30 and honey (F9) and in F10, PVP K30 was omitted. But in the two last formulations weak granules obtained and flowability was not suitable. Accordingly, honey and PVP K30 were increased again, however Avicel PH-102 was used instead of lactose, $\mathrm{SiO}_{2}$ was increased and magnesium stearate decreased (F11). This formulation was good but the tablet weight was high which induced pressure on the pressing machine. In the next formulation (F12), croscarmellose sodium was deleted and Avicel PH-101 as an intragranular disintegrator was added but disintegration time was again high. So, croscarmellose sodium was added but the weight was increased (F13). Then the weight was decreased by reduction of PVP K30 and croscarmellose sodium but it showed no satisfactory results (F14). During the next formulation, Avicel PH-101 and croscarmellose decreased but low compressibility was found (F15). Finally, in order to obtain good compressibility, Avicel PH-101 was omitted and $60 \mathrm{mg}$ lactose was added to the formulation (F16) which resulted completely suitable formulation regarding to physical properties such as disintegration time, friability, hardness and compressibility. It was good enough for coating process. Physical properties of different tablet formulations have been summarized in Table 3.

The coated tablets were light green in color, with mild odor of C. sativum. Assay of total tannins as pyrogallol showed 64.36 and 64.19 $\mathrm{mg} / \mathrm{tab}$ in core and coated tablet, respectively. Assessment of dissolution behavior of tablets in 30, 45 and 60 min showed after 60 min $91.5 \%$ of tannins were released which is in agreement with USP criteria (NLT $75 \%$ in $60 \mathrm{~min}$ ) (Table 4).

Physicochemical characteristics of Coriander Triphala tablets have been shown in Table 5. The stability studies demonstrated no significant changes in tablets attributes. 
Table 3. The results of physical characteristics of different formulation of Coriander Triphala

\begin{tabular}{cc}
\hline No. & Physical characteristics \\
\hline F1 & Oily, good hardness, high disintegration time \\
F2 & Oily, moderate hardness and compressibility \\
F3 & Good hardness, high disintegration time \\
F4 & Good hardness, high disintegration time \\
F5 & Good hardness, high disintegration time \\
F6 & Good hardness, high disintegration time \\
F11 & Good compressibility and disintegration time, high weight \\
F12 & Good compressibility, high disintegration time \\
F13 & Good compressibility and disintegration time, high weight \\
F14 & Good compressibility and disintegration time, induced pressure on instrument \\
F15 & Moderate compressibility, good disintegration time \\
F16 & Good compressibility, hardness, disintegration time and friability, suitable for coating \\
\hline
\end{tabular}

Table 4. Dissolution behavior of Coriander Triphala tablet

\begin{tabular}{|c|c|c|c|c|c|c|}
\hline \multirow{3}{*}{ Sample no. } & \multicolumn{6}{|c|}{ Percentage of total tannins as pyrogallol release } \\
\hline & \multicolumn{3}{|c|}{ Core } & \multicolumn{3}{|c|}{ Coated tablet } \\
\hline & $30 \mathrm{~min}$ & $45 \mathrm{~min}$ & $60 \mathrm{~min}$ & $30 \mathrm{~min}$ & $45 \mathrm{~min}$ & $60 \mathrm{~min}$ \\
\hline 1 & 71.2 & 90.1 & 96.3 & 65.3 & 88.6 & 94.1 \\
\hline 2 & 68.3 & 92.3 & 97.4 & 63.07 & 89.2 & 93.2 \\
\hline 3 & 68.5 & 95.1 & 93.2 & 63.51 & 86.5 & 89.3 \\
\hline 4 & 72.5 & 89.3 & 93.6 & 66.2 & 85.4 & 91.3 \\
\hline 5 & 70.9 & 88.2 & 95.4 & 65.2 & 85.9 & 92.6 \\
\hline 6 & 73.5 & 89.2 & 95.8 & 63.5 & 87.3 & 88.3 \\
\hline Mean \pm SD & $70.8 \pm 2.1$ & $90.7 \pm 2.6$ & $95.2 \pm 1.6$ & $64.5 \pm 1.3$ & $87.2 \pm 1.5$ & $91.5 \pm 2.3$ \\
\hline
\end{tabular}

Table 5. Physicochemical characteristics of Coriander Triphala tablets

\begin{tabular}{ccc}
\hline Test & core & coated tablet \\
\hline Appearance & Oval, biconvex, brown tablet & Oval, biconvex, light green tablet \\
\hline Weight variation & $1192 \mathrm{mg} \pm 5 \%$ & $1225 \mathrm{mg} \pm 5 \%$ \\
Thickness & $6.96 \mathrm{~mm} \pm 5 \%$ & $7.00 \mathrm{~mm} \pm 5 \%$ \\
Length & $20.19 \pm 2 \%$ & $20.20 \pm 2 \%$ \\
Diameter & $9.67 \pm 2 \%$ & $9.70 \pm 2 \%$ \\
Disintegration time & $19 \mathrm{~min}$ & $25 \mathrm{~min}$ \\
Dissolution, 60 min & $95.2 \%$ & $91.5 \%$ \\
Hardness & $18 \mathrm{kp}$ & $20 \mathrm{kp}$ \\
Assay of total tannins as pyrogallol & $64.36 \mathrm{mg} / \mathrm{tab}$ & $64.19 \mathrm{mg} / \mathrm{tab}$ \\
\hline
\end{tabular}

\section{Discussion}

Triphala is a popular formulation in traditional medicine containing the fruits of $T$. chebula, T. bellirica and Ph. emblica that is used as a single form or in combination with other species for different diseases. Coriander Triphala which is mixture of Triphala, $C$. sativum fruits, almond oil and honey, is used in Iranian traditional medicine from ancient's times $[4,5]$. In this investigation, the traditional formulation has been converted to tablet form in order to better acceptance, more efficacy and stability. This 
formulation contains honey, causing some problems during formulation. The results showed that increasing honey concentration induced higher disintegration time. In fact, honey as one of the active ingredients, played a binder role in the formulation as well. However, in order to obtain suitable granules, it was also necessary to use other binder (PVP K30) in the formulation. The honey percentage was very important because it not only induced high disintegration time of the tablets but also it increased drying time of granules. Thus in the case of honey presence in a formulation, usage of disintegrators such as croscarmellose sodium is an obligation. Less honey percentage in the tablet formulation decreases drying time of granules. High drying time causes waste of time and also produces a carcinogen substance namely hydroxy methyl furfural (HMF) due to honey degradation.

In the other hand, almond oil concentration should be noticed to prevent forming oily formulations which is not appropriate. Different formulations of Coriander Triphala demonstrated Avicel was the better diluent compared to lactose which gave adequate compressibility but a few amount of lactose as intra-granular binder was required. Finally, Coriander Triphala tablet was formulated by using natural ingredients along with lactose, Avicel PH-102, magnesium stearate, silicon dioxide, croscarmellose sodium and PVP K30. Coriander Triphala contains $C$. sativum fruits which is rich in essential oil. Due to volatile characteristics of these secondary metabolites, it is necessary to protect them from degradation and evaporation. In order to protect tablet ingredients especially volatile ones, the tablets were coated using water soluble film coting material. Tablet coating not only increases the stability but also the tablet has more acceptable appearance.
Since tannins are the major chemical components in Coriander Triphala tablet constituents [9-13], it was logical to evaluate the prepared tablets respect to tannins content; therefore, these chemical constituents were considered as marker for assay and dissolution studies of the tablets. The results showed that tablets contained remarkable amount of tannins and these chemicals were released from tablets during $60 \mathrm{~min}$ (acceptance level: minimum $75 \%$ ). All physicochemical properties of prepared tablets were in agreement with USP requirements for coated tablets [21].

Tablets are prepared by using three methods of direct compression, dry granulation and wet granulation. Direct compression and dry granulation are more common in herbal formulations due to easier process and no usage of temperature which may cause decomposing of chemical constituents [24, 25]. For example, during a study, Triphala tablets were prepared by slugging method during a dry granulation process [2]; but in Coriander Triphala tablets, due to honey in the formulation, the usage of wet granulation process and drying in $40^{\circ} \mathrm{C}$ was an obligation. During another study on formulation of Triphalaguggulkalpa tablets which is a mixture of Triphala with Commiphora mukul and Ficus benjamina, three types of tablet preparation were compared and it was proved that direct compression was preferable method regarding physicochemical properties of tablets [24]. During another research on different formulations of Triphala, wet granulation and direct compression techniques using Triphala powder and its extract were compered. Different excipients were used for preparing Triphala tablets and it was found that direct compression method was better than wet granulation and cocrystallized lactose-microcrystalline cellulose and alcoholic PVP proved to be the best diluent 
and binder, respectively. This study also demonstrated the tablets of Triphala powder had high friability compared to tablet of Triphala extract and the last one was preferred [3]. However, in the recent study, despite of using Triphala powder in the preparation of Coriander Triphala tablet, the tablets had reasonable hardness and friability which was due to PVP $\mathrm{K} 30$ and honey in the formulation.

\section{Conclusion}

The formulated Coriander Triphala film coated tablet containing lactose, Avicel PH-102, croscarmellose sodium, PVP K30, silicon dioxide and magnesium stearate showed reasonable physicochemical characteristics with appropriate tannins release behavior. It was stable during accelerated stability process and it could be a good candidate for industrial

\section{References}

1. Peterson CT, Denniston K and Chopra D. Therapeutic uses of Triphala in Ayurvedic medicine. J. Altern. Complement. Med. 2017; 23(8): 607-614. doi: 10.1089/acm.2017.0083.

2. Vibhushree Kumar TV, Manjunath $K$ and Anantha Narayana DB. Dry granulation technique for converting Triphala churna as granules, tablets and organoleptic evaluation. Int. Res. J. Pharm. 2015; 6(6): 321-326. doi: 10.7897/2230-8407.06669.

3. Momin M, Amin AF and Pundarikakshudu

P. Development and evaluation of triphala formulations. Indian J. Pharm. Sci. 2004; 66(4): 427-432.

4. Aghili Khorasani MH. Qarabadin-e kabir. Ostad Allah Qoli Khan Qajarpublisher. Tehran. 1855.

5. Nazem Jahan MA. Qarabadin-e Azam. Iran University of Medical Sciences. Tehran. 2004.

6. Sadeghi F, Fazljou SMB, Sepehri B, Khodaie $\mathrm{L}$ and Monirifar H. Effects of Pistacia lentiscus production after complementary studies especially adequate clinical trials.

\section{Author contributions}

R. C. and H. H. designed and supervised the project. K. M. and H. K. involved in tablet formulation. F. T. and L. A. performed quality control tests.

\section{Acknowledgements}

The authors wish to thank Traditional Medicine and Materia Medica Research Center, Shahid Beheshti University of Medical Sciences for laboratory supports.

\section{Conflict of Interest}

The authors declare that there is no conflict of interest.

and Coriander Triphala on adult gastroesophageal reflux disease: a randomized double-blinded clinical trial. Iran. Red Crescent Med. J. 2020; 22(6): e102260. doi: 10.5812/ircmj. 102260 .

7. Frawley D and Lad V. The yoga of herbs: an ayurvedic guide to herbal medicines. Lotus Press. Santa Fe. 1986, pp. 174.

8. Varnick PK, Nambiar VPK and Ramakuthy $\mathrm{C}$ (Eds). Indian medicinal plants: a compendum of 500 species. Vol. 5. Orient Longman. Hyderabad.1996, pp. 263.

9. Prakash SS, Patra N, Santanu C, Kumar PH, Patro J and Devi V. Studies on Flowability, compressibility and In-vitro release of Terminalia chebula fruit powder tablets. Iran. J. Pharm. Res. 2011; 10(1): 3-11.

10. Chattopadhyay RR and Bhattacharyya SK. Terminalia chebula: an update. Pharmacogn. Rev. 2007; 1(1): 151-156. 
11. Kumari S, Mythili Krishna J, Joshi AB, Gurav S, Bhandarkar AV, Agarwal A, Deepak $M$ and Gururaj GM. A pharmacognostic, phytochemical and pharmacological review of Terminalia bellerica. J. Pharmacogn. Phytochem. 2017; 6(5): 368-376.

12. Deb A, Barua $S$ and Das B. Pharmacological activities of Baheda (Terminalia bellerica): A review. J. Pharmacogn. Phytochem. 2016; 5(1): 194-197.

13. Variya BC, Bakrania $A K$ and Patel SS. Emblica officinalis (Amla): A review for its phytochemistry, ethnomedicinal uses and medicinal potentials with respect to molecular mechanisms. Pharmacol. Res. 2016; 111: 180200. doi: 10.1016/j.phrs.2016.06.013.

14. Al-Snafi AE. A review on chemical constituents and pharmacological activities of Coriandrum sativum. IOSR J. Pharm. 2016; 6(7): 17-42. doi: 10.9790/3013-067031742.

15. Aulton ME Ed. Pharmaceutics. The Science of dosage form design. Translated by Afrasiabi Garekani H, Tafaghodi M, Sajjadi SA and Sadeghi F. Mashhad University of Medical Sciences. Mashhad. 2005.

16. Rezghi M, Mortazavi SA, Fahimi Sh, Choopani R, Sheikholeslami MA and Hamzeloo-Moghadam M. Polyherbal tablet based on Iranian traditional medicine. J. Med. Plants. 2021; 20(77): 15-25.

17. Editorial Board. British Pharmacopoeia. The Stationary Office. London. 2015.

18. Hajimehdipoor $\mathrm{H}$, Nikmanesh $\mathrm{N}$ and Mohammadi-Motamed S. Amla oil, a pharmaceutical product based on traditional knowledge for hair loss treatment. Res. J. Pharmacogn. 2019; 6(1): 57-61. doi: 10.22127/RJP.2018.80373.

19. Moein E, Hajimehdipoor $H$, Toliyat $T$, Choopani R and Hamzeloo-Moghadam M. Formulation of an aloe-based product according to Iranian traditional medicine and development of its analysis method. DARU J. Pharm. Sci. 2017; 25(19): 1-9. doi: 10.1186/s40199-017-0185-x.

20. Dehdari S, Hajimehdipoor H, Esmaeili S, Mortazavi SA and Choopani R. Formulation and finger printing of a poly herbal film-coated tablet for treatment of hemorrhoids. Res. J. Pharmacogn. 2020; 7(4): 39-47. doi: 10.22127/RJP.2020.238203.1609.

21. Editorial Board. United States Pharmacopeia 39, National Formulary 34. USP Convention. Rockville. 2016.

22. European Medicine Agency. ICH Q1A (R2). Stability testing of new drug substances and drug products. EMEA. London. 2003, 1-20. 23. Row RC, Sheskey PJ and Quinn ME. Handbook of pharmaceutical excipients. Pharmaceutical Press. London. 2009.

24. Savarikar SS, Barbhind MM, Halde UK and Kulkarni AP. Pharmaceutical and analytical evaluation of triphalaguggulkalpa tablets. $J$. Ayur. Integr. Med. 2011; 2(1): 21-25. doi: 10.4103/0975-9476.78187.

25. Vaishali S, Deepika R, Anuj K and Himanshu C. Formulation and evaluation of herbal tablet containing Terminalia chebula extract. Lett. App. NanoBioSci. 2019; 8(4): 692697. doi: 10.33263/LIANBS84.692697.

How to cite this article: Choopani R, Hajimehdipoor H, Molaei K, Kashafroodi H, Tavakolifar F, Ara L. Formulation and quality evaluation of Coriander Triphala tablet. Journal of Medicinal Plants 2021; 20(78): 68-77.

doi: $10.52547 / j m p .20 .78 .68$ 


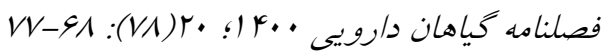

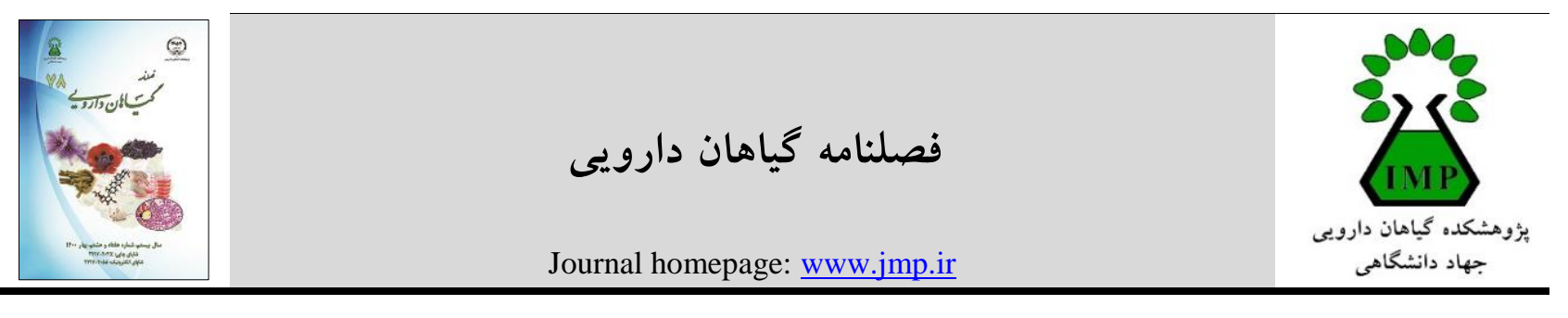

مقاله تحقيقاتى

\section{فرمولاسيون و كنترل كيفيت قرص اطريفل گثشنيزى}

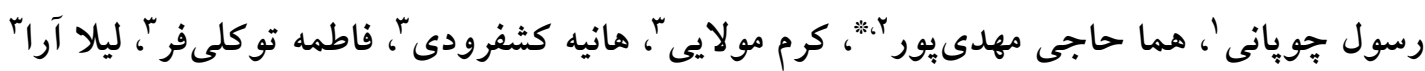

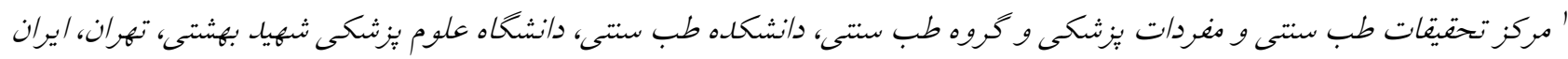

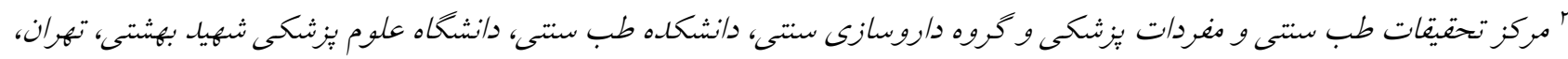

r مركز تحقيقات طب سنتى و مغردات بزشكى، دانشكاه علوم بز شكى شهيد بهشتى، تهران، ايران

\begin{tabular}{|c|c|}
\hline جكيده & 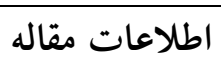 \\
\hline مقدمه: اطريفل گشنيزى يكى از داروهاى برمصرف در طب سنتى است كه شامل هليله، بليله، آمله، تخم گشنيز، & 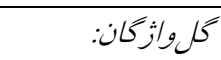 \\
\hline روغن بادام و عسل است. فرمهاى دارويى سنتى جهت بهبود خصوصيات، پايدارى و نيز بذيرش بهتر توسط بيماران & 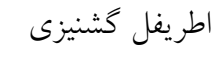 \\
\hline بايد به فرمهاى جديد تبديل شوند. هدف: در تحقيق حاضر، فرم سنتى معجون اطريفل كشنيزى به قرص روكشدار & قرص \\
\hline تبديل شده و كتترل كيفيت آن انجام شده است. روش بررسى: ميوههاى هليله سياه، هليله زرد، هليله كابلى، بليله، & فرمولاسيون \\
\hline آمله و كَشنيز در مقادير مساوى همراه با روغن بادام، عسل و ساير اكسيييانها در مقادير مختلف براى فرمولاسيون & طب سنى ايران \\
\hline قرص مورد استفاده قرار كرفتند. شانزده فرمولاسيون تهيه شد و بعد از مطالعات بيش فرمولاسيون، دوازده فرمول & كنترل كيفيت \\
\hline براى ساخت قرص انتخاب شدند. قرصهاى ساخته شده تستهاى كنترل كيفيت اوليه شامل انحراف وزن، & \\
\hline فرسايش، سختى و زمان باز شدن را سيرى كرده و درنهايت بهترين فرمولاسيون انتخاب و توسط رنخ سبز محلول & \\
\hline در آب روكش داده شد و خصوصيات فيزيكوشيميايى آن تعيين شد. نتايج: در ميان فرمولاسيونهاى مختلف، قرص & \\
\hline 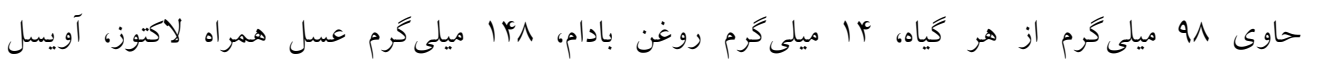 & \\
\hline PH-102، كراس كارملوز سديم، يلى وينيل بيروليدون K30، منيزيم استئارات و سيليكون دى اكسايد بهترين آنها & \\
\hline 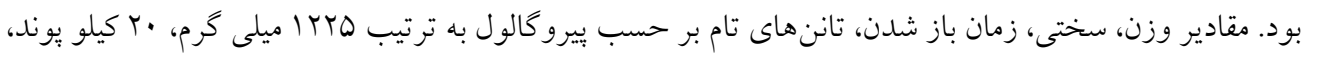 & \\
\hline 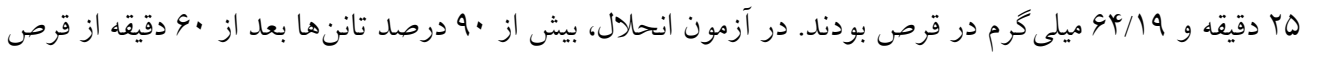 & \\
\hline آزاد شده بودند. نتيجه گيرى: قرص فرموله شده با خصوصيات فيزيكوشيميايى مناسب جايكزين خوبى براى فرم & \\
\hline سنتى معجون بوده و مى تواند ٍِ از طى آزمونهاى بالينى در مقياس صنعتى توليد شود. & \\
\hline
\end{tabular}

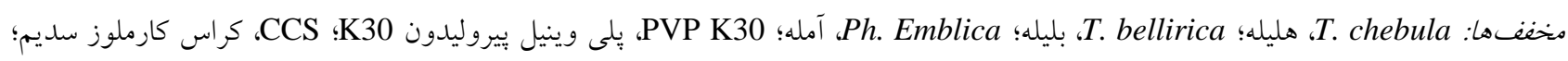

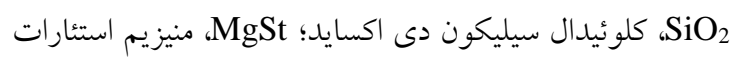

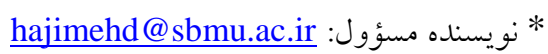
doi: $10.52547 /$ jmp. 20.78 .68

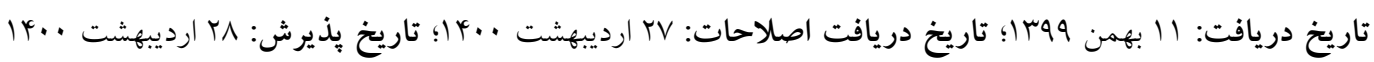
(c) 2020. Open access. This article is distributed under the terms of the Creative Commons Attribution-NonCommercial 4.0 International License (https://creativecommons.org/licenses/by-nc/4.0/) 